\title{
Population Structure of Xylella fastidiosa Associated with Almond Leaf Scorch Disease in the San Joaquin Valley of California
}

\author{
Hong Lin, Md Sajedul Islam, Juan C. Cabrera-La Rosa, Edwin L. Civerolo, and Russell L. Groves
}

First, second, and fourth authors: United States Department of Agriculture-Agricultural Research Service (USDA-ARS) San Joaquin Valley Agricultural Sciences Center, 9611 South Riverbend Avenue, Parlier, CA 93648-9757; second author: Department of Viticulture and Enology, University of California, Davis 95616; third author: Universidad Privada Antenor Orrego, Trujillo, Perú; and fifth author: Department of Entomology, University of Wisconsin, Madison 53706.

Accepted for publication 19 February 2015.

\begin{abstract}
Lin, H., Islam, M. S., Rosa, J. C. C.-L., Civerolo, E. L., and Groves, R. L. 2015. Population structure of Xylella fastidiosa associated with almond leaf scorch disease in the San Joaquin Valley of California. Phytopathology 105:825-832.

Xylella fastidiosa causes disease in many commercial crops, including almond leaf scorch (ALS) disease in susceptible almond (Prunus dulcis). In this study, genetic diversity and population structure of $X$. fastidios $a$ associated with ALS disease were evaluated. Isolates obtained from two almond orchards

analyzed for two successive years. Multilocus simple-sequence repeat (SSR) analysis revealed two major genetic clusters that were associated with two host cultivars, 'Sonora' and 'Nonpareil', respectively, regardless of the year of study or location of the orchard. These relationships suggest that host cultivar selection and adaptation are major driving forces shaping ALS X. fastidiosa population structure in the San Joaquin Valley. This finding will provide insight into understanding pathogen adaptation and host selection in the context of ALS disease dynamics.
\end{abstract} in Fresno and Kern County in the San Joaquin Valley of California were

Almond leaf scorch (ALS) disease $(9,15,36,49)$ in susceptible almond (Prunus dulcis (Mill.) D. A. Webb) is caused by Xylella fastidiosa (61), a xylem-limited, fastidious bacterium. Several subspecies (i.e., subsp. fastidiosa, multiplex, and pauca) $(16,53,54)$, have been suggested or proposed based on the distinct genetic and phylogenetic clades $(40,45,54,56,62)$ of $X$. fastidiosa associated with diseases of a wide range of agricultural, horticultural, and landscape plants throughout the Americas $(23,39,53,54)$. Important diseases of fruit trees and vine crops include ALS (36), Pierce's disease (PD) of grape (14), oleander leaf scorch (OLS) (44), citrus variegated chlorosis (CVC) (27), phony peach and plum leaf scald (13), coffee leaf scorch (CLS) $(2,11)$, pear leaf scorch $(28,56)$, and pecan bacterial leaf scorch $(34,50)$. Pathogenic strains of $X$. fastidiosa subsp. multiplex have been associated with leaf scorch or dieback symptoms in some olive trees in California (26). X. fastidiosa strains have recently been detected in almond and olive trees and oleander plants, exhibiting leaf scorch symptoms in Apulia, Italy (32,51). In addition, $X$. fastidiosa strains closely related to $X$. fastidiosa subsp. pauca were identified in olive trees associated with a quick decline syndrome and with diseased oleander in Apulia, Italy (5).

California produces $82 \%$ of the almond nuts globally, and the San Joaquin Valley (SJV) of California is a major almond-producing region. ALS is a difficult plant disease to manage effectively. $X$. fastidiosa has been present in the $\operatorname{SJV}(36,43,49)$ and has threatened both grape and almond production for many years. ALS disease has reemerged as a potential threat to the almond industry in the $\operatorname{SJV}(3,8,9,19)$.

Corresponding author: H. Lin; E-mail address: Hong.Lin@ars.usda.gov

*The $\boldsymbol{e}$-Xtra logo stands for "electronic extra" and indicates that one supplementary figure and one supplementary table are published online.

http://dx.doi.org/10.1094/PHYTO-09-14-0254-R

This article is in the public domain and not copyrightable. It may be freely reprinted with customary crediting of the source. The American Phytopathological Society, 2015
Additional keywords: annual variation.
$X$. fastidiosa strains associated with ALS disease are spread within and among almond orchards by sharpshooter leafhoppers or spittlebugs while they feed in the xylem. The disease develops slowly over several years, infecting more trees with each succeeding year (58). After a few years following infection, affected trees become unproductive and may die.

Genetic and pathogenic variations of phytopathogenic bacteria significantly affect disease epidemiology. Limited variation in genetic diversity and structure among crop cultivars may impose strong selection on $X$. fastidiosa strains. On the other hand, large genetic variations in pathogen populations can lead to breakdown of host resistance. Crop resistance durability depends upon the variability and adaptability of pathogen populations as they interact with host plant resistance genes. Therefore, information about the genetic diversity and genetic population structure of $X$. fastidiosa responsible for ALS disease in the SJV is important to help develop effective disease management strategies.

Groves et al. (19) analyzed the spatial distributions and spread of $X$. fastidiosa strains associated with ALS disease in the SJV and detected the variation of disease incidence among different host cultivars. Chen et al. (8) characterized $X$. fastidiosa strains associated with ALS disease in the SJV and reported two distinct genotypes in the same infected almond orchard, although it was not clear whether these two distract genotypes were associated with particular host cultivars. Although these studies provided some background information about the distribution of ALS disease-associated X. fastidiosa strains in the SJV, information regarding the spatial and temporal variations in genetic diversity and population structure in the context of disease epidemiology is lacking.

Simple-sequence repeat (SSR) markers, also known as variablenumber tandem repeat (VNTR) or microsatellite markers, are effective tools for tracking spatial and temporal variation in genetic diversity and population differentiation. This marker system possesses adequate discrimination power for distinguishing and clustering bacterial populations that have evolved over a short time scale. SSR makers have been successfully used to evaluate genetic diversity 
and population structure of various plant-pathogenic bacteria such as in 'Candidatus Liberibacter' spp. $(21,30)$ and Xanthomonas citri (59), including Xylella fastidiosa-associated diseases in various agricultural and horticultural crops such as PD in grape (10,29,31), CVC in citrus, and CLS $(2,11)$.

An SSR marker system containing 34 loci was previously developed from the genome sequences of four different strains of $X$. fastidiosa which cause PD, CVC, ALS, and OLS diseases, respectively (29). Ten of these markers successfully genotyped $X$. fastidiosa strains that cause ALS disease and were used in the present study to analyze the seasonal and annual variation in genetic diversity and genetic population structure of this bacterium in two almond orchards in the SJV of California: orchard A in Fresno County and orchard B in Kern County. Isolates obtained from these almond orchards were analyzed over multiple growing seasons.

The objectives of this study were to track the spread of virulent $X$. fastidiosa strains among different host cultivars throughout the almond production season within a year and between successive years. Such information is critical for the development of effective disease management strategies.

\section{MATERIALS AND METHODS}

Study site and sample collections. The study almond orchards, orchard A and orchard B, were located in the central (Fresno County) and southern (Kern County) portions of the SJV, respectively. These two almond orchards are separated by approximately $250 \mathrm{~km}$. Orchard A was planted in 1988 and consisted of alternating, four-row blocks of different almond cultivars: 'Nonpareil' (50\%), 'Sonora' (25\%), and 'Carmel' (25\%). Orchard B orchard was planted between 1995 and 1996 and was arranged as alternating four-row blocks of Nonpareil (50\%), Sonora (25\%), and 'Fritz' (25\%).

Only Sonora was X. fastidiosa infected in orchard A; however, two cultivars, including Sonora and Nonpareil, were affected with ALS symptoms in orchard B. Symptomatic almond shoots were collected from Sonora at both experimental orchards. Nonpareil shoots were collected in orchard B. Samples were collected throughout the almond growing seasons (May to October) in 2004 (monthly) and 2005 (bimonthly) from each of the experimental sites. Each sample was collected from and represented for an individual symptomatic tree.

$X$. fastidiosa isolation. Symptomatic shoots were initially surface sterilized by quick immersion in $85 \%$ ethanol followed by flaming. A 3- to 5-cm shoot piece was inserted into a tube containing $20 \mu \mathrm{l}$ of sterilized water. The tube was then centrifuged to extract $X$. fastidiosa-containing sap. Sap extracts were then streaked on periwinkle wilt (PW) agar medium and incubated at $28^{\circ} \mathrm{C}$ for 15 to 20 days (13). Isolated colonies were verified by polymerase chain reaction (PCR) using primers RST31 and RST33, specific for $X$. fastidiosa (35). Isolated $X$. fastidiosa colonies were archived in PW broth with $30 \%$ glycerol and stored at $-80^{\circ} \mathrm{C}$. In total, 146 isolates were collected and represented two experimental

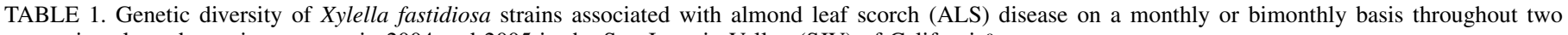
successive almond growing seasons in 2004 and 2005 in the San Joaquin Valley (SJV) of California ${ }^{\mathrm{a}}$

\begin{tabular}{|c|c|c|c|c|c|c|c|c|c|}
\hline Collection ID & Year & Month & Orchard & Cultivar & $\mathrm{N}$ & $\mathrm{Nec}$ & $\mathrm{Na}$ & $\mathrm{Ne}$ & Hs \\
\hline \multicolumn{10}{|l|}{ Sonora 2004} \\
\hline $4 \mathrm{mMs}$ & 2004 & May & Orchard A & Sonora & 4 & 3 & 1.3 & 1.2 & 0.133 \\
\hline $4 \mathrm{mJs}$ & 2004 & June & Orchard A & Sonora & 5 & 4 & 1.4 & 1.3 & 0.138 \\
\hline $4 \mathrm{mJLs}$ & 2004 & July & Orchard A & Sonora & 5 & 4 & 1.5 & 1.3 & 0.175 \\
\hline $4 \mathrm{mAs}$ & 2004 & August & Orchard A & Sonora & 5 & 5 & 2.7 & 2.2 & 0.496 \\
\hline $4 \mathrm{mSs}$ & 2004 & September & Orchard A & Sonora & 5 & 4 & 1.4 & 1.3 & 0.138 \\
\hline $4 \mathrm{mOs}$ & 2004 & October & Orchard A & Sonora & 5 & 4 & 1.4 & 1.3 & 0.138 \\
\hline Total & $\ldots$ & $\ldots$ & $\ldots$ & $\ldots$ & 29 & 24 & 1.6 & 1.4 & 0.203 \\
\hline \multicolumn{10}{|l|}{ Sonora 2005} \\
\hline $5 \mathrm{mMs}$ & 2005 & May & Orchard A & Sonora & 5 & 4 & 1.6 & 1.5 & 0.213 \\
\hline $5 \mathrm{mJLs}$ & 2005 & July & Orchard A & Sonora & 9 & 5 & 1.5 & 1.3 & 0.152 \\
\hline $5 \mathrm{mOs}$ & 2005 & October & Orchard A & Sonora & 14 & 5 & 1.6 & 1.4 & 0.192 \\
\hline Total & $\ldots$ & $\ldots$ & $\ldots$ & $\ldots$ & 28 & 14 & 1.6 & 1.4 & 0.186 \\
\hline \multicolumn{10}{|l|}{ Sonora 2004} \\
\hline 4rMs & 2004 & May & Orchard B & Sonora & 3 & 3 & 2.1 & 2.0 & 0.422 \\
\hline $4 \mathrm{rJs}$ & 2004 & June & Orchard B & Sonora & 4 & 4 & 2.4 & 2.2 & 0.475 \\
\hline 4rJLs & 2004 & July & Orchard B & Sonora & 3 & 3 & 2.3 & 2.2 & 0.489 \\
\hline $4 \mathrm{rAs}$ & 2004 & August & Orchard B & Sonora & 4 & 3 & 1.2 & 1.2 & 0.067 \\
\hline $4 \mathrm{rSs}$ & 2004 & September & Orchard B & Sonora & 4 & 4 & 2.4 & 2.2 & 0.500 \\
\hline $4 \mathrm{rOs}$ & 2004 & October & Orchard B & Sonora & 4 & 4 & 2.5 & 2.3 & 0.525 \\
\hline Total & $\ldots$ & $\ldots$ & $\ldots$ & $\ldots$ & 22 & 21 & 2.2 & 2.0 & 0.413 \\
\hline \multicolumn{10}{|l|}{ Nonpareil 2004} \\
\hline 4rMnp & 2004 & May & Orchard B & Nonpareil & 3 & 2 & 1.6 & 1.6 & 0.300 \\
\hline 4rJnp & 2004 & June & Orchard B & Nonpareil & 3 & 2 & 1.4 & 1.4 & 0.200 \\
\hline 4rJLnp & 2004 & July & Orchard B & Nonpareil & 4 & 2 & 1.4 & 1.4 & 0.200 \\
\hline 4rAnp & 2004 & August & Orchard B & Nonpareil & 3 & 3 & 1.5 & 1.4 & 0.200 \\
\hline $4 \mathrm{rSnp}$ & 2004 & September & Orchard B & Nonpareil & 4 & 4 & 2.0 & 1.9 & 0.288 \\
\hline 4rOnp & 2004 & October & Orchard B & Nonpareil & 4 & 4 & 1.6 & 1.4 & 0.213 \\
\hline Total & $\ldots$ & $\ldots$ & $\ldots$ & $\ldots$ & 21 & 17 & 1.6 & 1.5 & 0.233 \\
\hline \multicolumn{10}{|l|}{ Sonora 2005} \\
\hline $5 \mathrm{rMs}$ & 2005 & May & Orchard B & Sonora & 5 & 4 & 2.5 & 2.2 & 0.463 \\
\hline $5 \mathrm{rJLs}$ & 2005 & July & Orchard B & Sonora & 6 & 4 & 2.3 & 2.0 & 0.475 \\
\hline $5 \mathrm{rOs}$ & 2005 & October & Orchard B & Sonora & 8 & 5 & 2.7 & 2.3 & 0.528 \\
\hline Total & $\cdots$ & $\cdots$ & $\ldots$ & $\ldots$ & $\ldots$ & $\ldots$ & 2.5 & 2.2 & 0.489 \\
\hline \multicolumn{10}{|l|}{ Nonpareil 2005} \\
\hline 5rMnp & 2005 & May & Orchard B & Nonpareil & 6 & 6 & 1.7 & 1.5 & 0.239 \\
\hline 5rJLnp & 2005 & July & Orchard B & Nonpareil & 11 & 4 & 1.5 & 1.4 & 0.188 \\
\hline 5rOnp & 2005 & October & Orchard B & Nonpareil & 10 & 6 & 1.9 & 1.5 & 0.244 \\
\hline Total & $\ldots$ & $\ldots$ & $\ldots$ & $\ldots$ & 27 & 16 & 1.7 & 1.5 & 0.224 \\
\hline
\end{tabular}

a Isolates were obtained from two almond orchards in the SJV (orchard A and orchard B) containing two almond cultivars (Sonora and Nonpareil). $\mathrm{N}=$ number of isolates, Ncc = number of isolates in clone-corrected data set, $\mathrm{Na}=$ number of alleles, $\mathrm{Ne}=$ number of effective alleles, and Hs = haploid genetic diversity. 
site-year combinations. Among them, 57 samples were collected from orchard A (29 isolates in 2004 and 28 isolates in 2005) and 89 samples were from orchard B (43 isolates in 2004 and 46 isolates in 2005). Specific information regarding the samples and strains isolated is presented in Table 1.

PCR. Ten SSR markers (ASSR9, ASSR12, CSSR7, CSSR10, CSSR12, GSSR4, GSSR20, OSSR12, OSSR17, and OSSR19) (29) that showed clear amplification and polymorphism across the ALSassociated $X$. fastidiosa strains were used in the present study. The forward primer for each of the SSR primer pairs was labeled with a fluorescent dye: FAM, NED, VIC, or PET. PCR was performed in a $20-\mu$ r reaction mix containing $2 \mu$ l of $10 \times$ reaction buffer (Applied Biosystems [ABI], Foster City, CA), $1.0 \mathrm{mM} \mathrm{MgCl}_{2}, 0.2 \mathrm{mM}$ dNTP, $0.25 \mathrm{U}$ of Taq polymerase, $2.5 \mathrm{pmol}$ each of SSR primers, and $2 \mu \mathrm{l}$ of diluted DNA sample. PCR was performed in the following conditions: initial denaturation at $95^{\circ} \mathrm{C}$ for $6 \mathrm{~min}$; followed by 35 cycles of $95^{\circ} \mathrm{C}$ for $30 \mathrm{~s}, 58^{\circ} \mathrm{C}$ for $30 \mathrm{~s}$, and $72^{\circ} \mathrm{C}$ for $1 \mathrm{~min}$; with a final extension step of $72^{\circ} \mathrm{C}$ for $7 \mathrm{~min}$. The amplified products were verified by agarose gel electrophoresis. For fragment analysis, $2 \mu \mathrm{l}$ of each PCR product labeled with different fluorescent dye was pooled. From this $8 \mu \mathrm{l}$ of pooled product, $2.5 \mu \mathrm{l}$ was mixed with $0.25 \mu$ of GeneScan-500 Liz molecular size standard (ABI catalog number 4322682A) and 7.25 $\mu \mathrm{l}$ of Hi-Di Formamide (ABI catalog number 4311320). The mixture of PCR products from different SSR was then loaded onto an Applied Biosystems 3100 Genetic Analyzer with the 36-cm 16-capillary array filled by polymer POP-4 module for analysis. Data acquisition and fragment size determinations were carried out by GeneMapper software (v4.0; Applied Biosystems).

Data analysis. The allelic data obtained from 10 SSR markers were combined and multilocus haplotypes were identified for all of the samples collected. A clone-corrected data set (excluding repeated haplotypes) for each of the collections (monthly and bimonthly) for two consecutive years was built and used for genetic diversity and genetic structure analyses.

GenAlEx version 6.3 (41) was used to calculate the average number of alleles $(\mathrm{Na})$, average number of effective alleles $(\mathrm{Ne})$, and haploid genetic diversity (Hs) across the all loci for each collection.

The association of alleles between each pair of SSR loci (linkage disequilibrium [LD]) for the clone-corrected data across the all collections was tested using a Fisher exact test implemented in GENEPOP web version 4.0.10 (46), with the default parameters for burn-in period $(n=1,000)$, number of batches $(n=100)$, and number of iterations per batch $(n=1,000)$. In addition, we measured the index of association $\left(I_{\mathrm{A}}\right)(4)$ and an alternative index, $\bar{r}_{d}$ (less biased to the number of loci) (1), to assess the multilocus genotypic LD within the populations obtained from orchard A (Sonora), and

TABLE 2. Distribution of Xylella fastidiosa haplotypes associated with almond leaf scorch disease (ALS) on a monthly or bimonthly basis throughout the almond growing seasons for the two successive years (2004 and 2005) in the San Joaquin Valley (SJV) ${ }^{\mathrm{a}}$

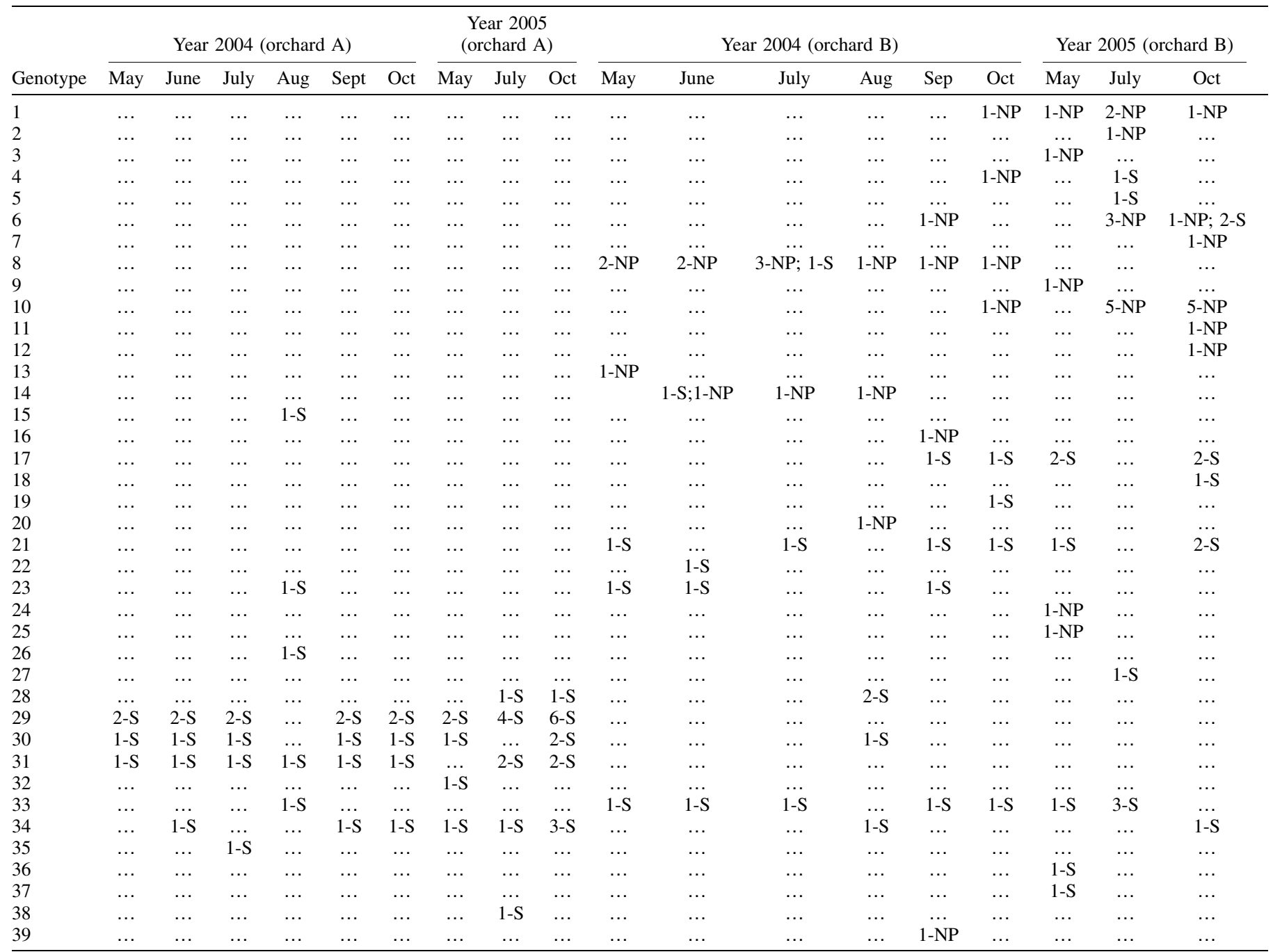

${ }^{a}$ Isolates were obtained from two almond orchards in the SJV (orchard A and orchard B) containing two almond cultivars (Sonora and Nonpareil). S = Sonora and $\mathrm{NP}=$ Nonpareil; number indicates the number of isolates. 
orchard B (Sonora and Nonpareil). This analysis was performed in the Poppr package in R environment (24). Both of these values significantly different from 0 signifies disequilibrium, which was tested by 999 permutations.

The seasonal and annual genetic variations in the genetic structure of $X$. fastidiosa populations were evaluated using various approaches. First, we performed an unweighted pair group method with arithmetic means (UPGMA) clustering analysis based on DA genetic distance (37). The trees were constructed by computing genetic distances between individual isolates using POPULATION software package version 1.2.31 (http://bioinformatics.org/ tryphon/ populations/) and graphically displayed with MEGA 4 software (57). Second, a principal coordinate analysis (PCoA) was performed to visualize spatial genetic variation of the sampled isolates obtained from two almond orchards. Here, genetic distances, calculated from the SSR allele data, were plotted as PCoA using GenAlEx (41). Finally, the genetic structure of $X$. fastidiosa populations was analyzed with a Bayesian clustering algorithm using STRUCTURE 2.3.1 (42), where an individual isolate can be assigned to a specified number of clusters $(\mathrm{K})$. We set 20 independent runs of $\mathrm{K}=1$ to 10 without prior information of the origin (season, year, location, or host) of the samples. A burn-in period of 25,000 iterations was used for each run followed by a run length of 50,000 Markov chain Monte Carlo iterations, and a linkage model (using the map distance between SSR loci based on their position in X. fastidiosa genome) with correlated allele frequencies. The model was run with 20 independent simulations for each $\mathrm{K}$. The number of clusters that best represented the observed data was determined by maximizing the estimated ln likelihood of the data for different values of $\mathrm{K}$ and the $\Delta \mathrm{K}$ index, which is based on the rate of change in the $\ln$ likelihood of the data between successive $\mathrm{K}(n=1$ to 20$)$ (17). The optimal probabilities for all individuals were estimated from 20 replicate runs at the inferred number of clusters with permutation analysis using CLUMPP 1.1.2 (22), and the output of genetic clustering was visualized using software DISTRUCT 1.1 (48).

\section{RESULTS}

The genetic diversity parameters (i.e., the $\mathrm{Na}, \mathrm{Ne}$, and $\mathrm{Hs}$ ) across the all SSR loci for the isolates obtained from two different almond

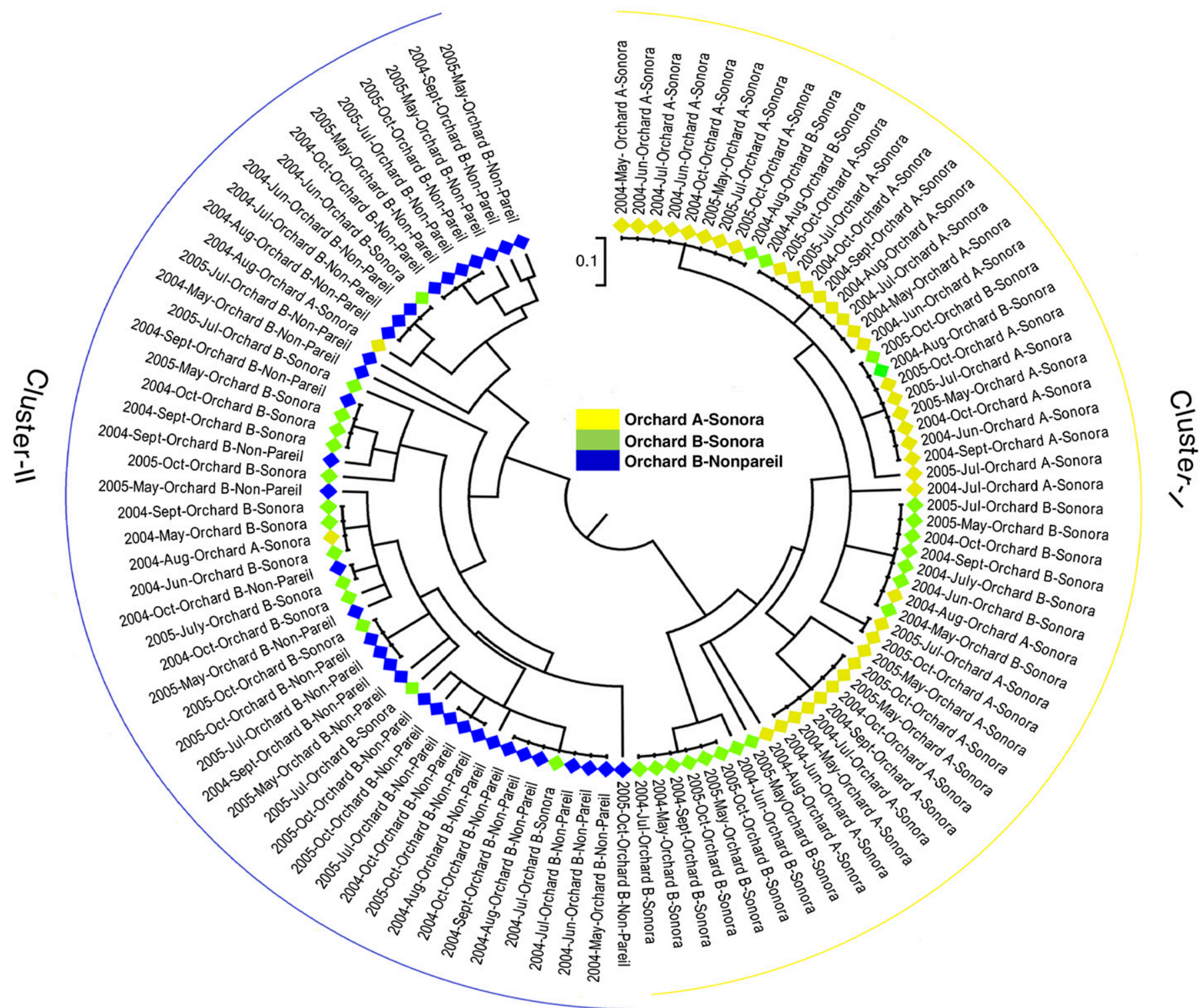

Fig. 1. Unweighted pair group method with arithmetic means (UPGMA) dendrogram across the Xylella fastidiosa isolates obtained from two almond orchards in the San Joaquin Valley of California (orchard A and orchard B) containing two almond cultivars (Sonora and Nonpareil). Isolates were obtained on a monthly or bimonthly basis throughout the almond growing seasons for the two successive years: 2004 (monthly) and 2005 (bimonthly). 
orchards in the two production years (2004 and 2005) are summarized in Table 1 . No seasonal or annual variation was observed in genetic diversity among the isolates at each of the study orchards. However, host-associated comparison of $X$. fastidiosa between two different host plant cultivars within the same orchard (orchard B) showed that genetic diversity was relatively higher in the collections from Sonora than that associated with Nonpareil (Table 1). However, the level of genetic diversity of $X$. fastidiosa associated with the same cultivar (Sonora) was different between the two almond orchards studied.

By combining allelic data across 10 SSR loci, 39 haplotypes were identified in a total of $146 \mathrm{X}$. fastidiosa isolates. The distribution of haplotypes across the sampling seasons and years at each of the study orchards is presented in Table 2 . No haplotypes were strictly associated with any particular season or year within each of the study orchards. That is, overlapping of several identical haplotypes of $X$. fastidiosa was observed throughout the almond growing seasons at each orchard for the two consecutive years. However, host-associated haplotypes were linked between the populations obtained from the two host cultivars. Although the overlapping of haplotypes was observed for the $X$. fastidiosa strains associated with
Sonora from the two different orchards, no single haplotype overlapped between Sonora and Nonpareil obtained from the two different orchards (orchard A and orchard B, respectively). Even within orchard B itself, the overlapping of identical haplotypes between Nonpareil and Sonora was minimal.

Two approaches were used to infer the presence of genotypic LD among the isolates. First, the strength of allelic association was verified by testing LD among SSR loci, where significant disequilibrium $(P \leq 0.01)$ was observed between the majority of the locus pairs ( 31 out of a total 45 pairs across 10 SSR loci) for the overall population (Supplementary Table S1). Second, multilocus genotypic disequilibrium was tested by the $I_{\mathrm{A}}$, where $I_{\mathrm{A}}$ and $\bar{r}_{d}$ was significantly different from $0(P \leq 0.01)$ within the population at each orchard or host cultivar (i.e., orchard A: $I_{\mathrm{A}}=2.719, \bar{r}_{d}=0.344$; and orchard B: Sonora, $I_{\mathrm{A}}=3.060, \bar{r}_{d}=0.0345$, and Nonpareil, $I_{\mathrm{A}}=$ $\left.0.588, \bar{r}_{d}=0.070\right)$ (Supplementary Fig. S1).

UPGMA, PCoA, and STRUCTURE analyses identified two major genetic groups or clusters (cluster I and cluster II) (Figs. 1, 2, and 3 , respectively). No seasonal or annual variations in genetic structure were observed among the isolates obtained from two different orchards; even haplotypes from different seasons and

Principal Coordinates (PCOA)

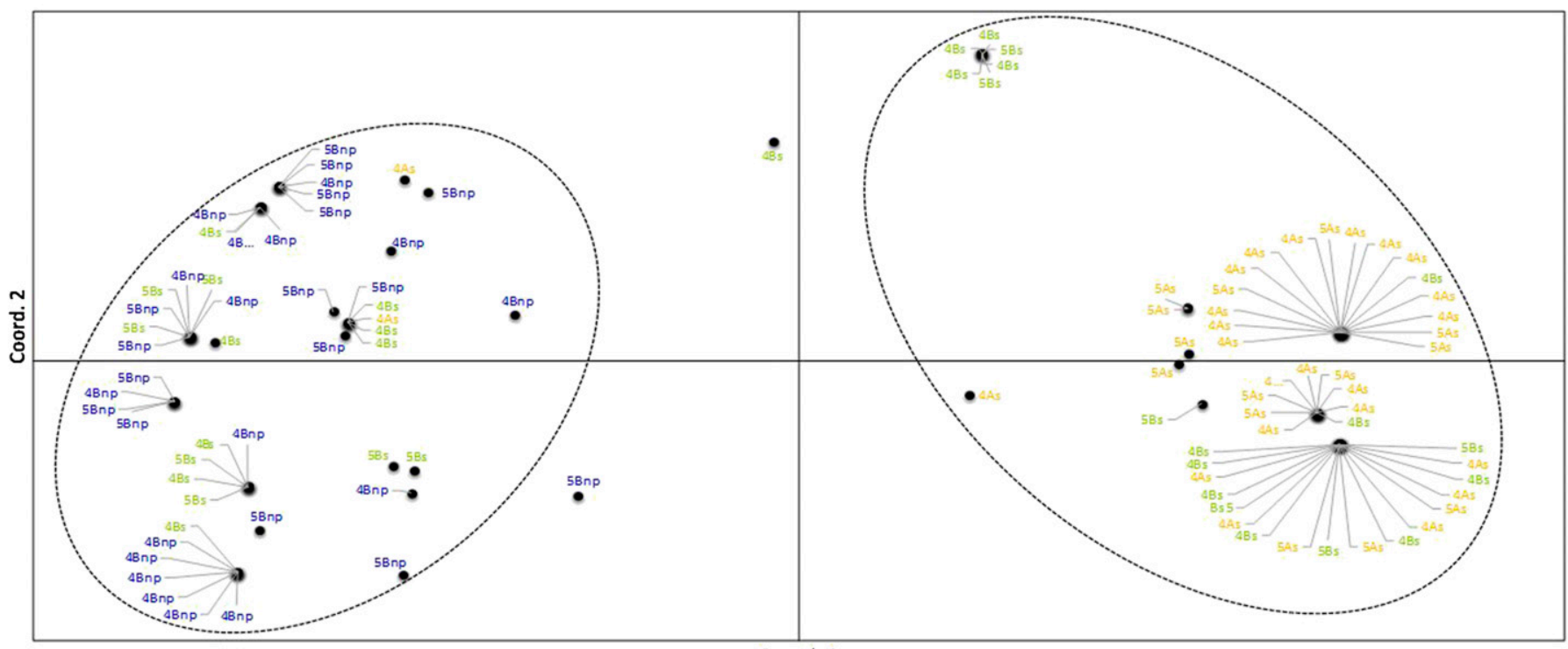

Coord. 1

Fig. 2. Principal coordinate analysis (PCoA) plot across the Xylella fastidiosa isolates obtained from two almond orchards in the San Joaquin Valley of California (orchard A and orchard B) containing two almond cultivars (Sonora and Nonpareil). Isolates were obtained on a monthly or bimonthly basis throughout the almond growing seasons for the two successive years: 2004 (monthly) and 2005 (bimonthly). In the PCoA plot, As, Bs, and Bnp indicate orchard A-Sonora, orchard B-Sonora, and orchard B-Nonpareil, respectively. Numbers 4 and 5 indicate sampling years 2004 and 2005, respectively.

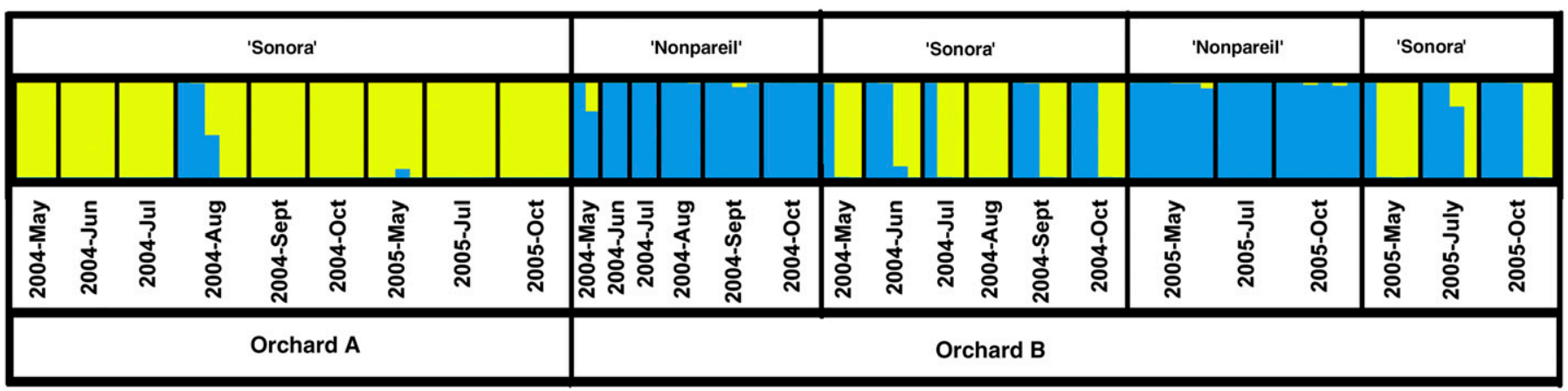

Fig. 3. Individual assignments (using STRUCTURE) of the Xylella fastidiosa isolates obtained from two almond orchards in the San Joaquin Valley of California (orchard A and orchard B) containing two almond cultivars (Sonora and Nonpareil). There were two clusters (K): cluster I (yellow) and cluster II (blue). Black lines within the squares distinguish the group of isolates. Isolates were obtained on a monthly or bimonthly basis throughout the almond growing seasons for the two successive years: 2004 (monthly) and 2005 (bimonthly). 
years overlapped in subclusters within each major cluster. Two major genetic groups or clusters, however, were mostly linked to the two almond cultivars Sonora (cluster 1) and Nonpareil (cluster 2) (Figs. 1, 2, and 3). Only a small number of isolates obtained from Sonora in orchard B (randomly throughout the seasons) and a very few isolates from orchard A (August 2004 only) were included in cluster 2 (Nonpareil dominant group).

\section{DISCUSSION}

Genetic analysis of $X$. fastidiosa strains associated with ALS disease in this study did not show any seasonal or annual variation in genetic diversity across the strains in two successive years (2004, monthly; 2005, bimonthly) or from the two geographically distant experimental orchards. Rather, genetic diversity was partitioned mainly based on the host associations. Although spatial analysis showed that the genetic diversity of $X$. fastidiosa strains is different within a cultivar (e.g., Sonora) between two different almond orchards (separated by approximately $250 \mathrm{~km}$ ), comparisons between two cultivars within the same orchard (e.g., orchard B) demonstrates that genetic diversity of $X$. fastidiosa strains is largely associated with host plants, where allelic and haploid diversity of $X$. fastidiosa within Sonora was more diverse than in Nonpareil.

$X$. fastidiosa has been reported to be able to colonize a number of host plants $(6,33,56)$. Within the SJV, ALS disease is widely distributed in almond production areas and is also associated with large areas of adjoining permanent pasture or irrigated alfalfa forage crops around the affected areas (61). Pathogen diversity in a particular almond production area may occur based on the capabilities of exploiting multiple reservoir species. X. fastidiosa strains are transmitted by insects including sharpshooter leafhoppers (Hemiptera: Cicadellidae) and spittlebugs (Hemiptera: Cercopidae) (43). The different level of genetic diversity for the same cultivar (Sonora) between two separate almond orchards may have been influenced by the respective population dynamics and degree of activeness of the insect vectors at each of the study areas. However, there is no evidence of vector specificity for $X$. fastidiosa, although transmission efficiency may vary among sap feeders $(8,18,25,47)$. The differential genetic diversity between Sonora and Nonpareil within the same orchard (orchard B) were most likely influenced by the host plant selection pressure. This is not unexpected because pathogenic variants of $X$. fastidiosa have been often described as plant host specific (23).

The bacterium has long been present in the SJV $(36,49)$ and has annually threatened grape and almond production for many years. Partitioned genetic diversity between two almond cultivars in this study suggests host differential selection pressure has affected $X$. fastidiosa populations, resulting in its adaptation and leading to host-associated genetic diversity and disease incidence in almond orchards in the SJV. The variation of genetic diversity based on host plants, and especially the higher level of genetic diversity associated with Sonora at orchard B in our analysis, agrees with the hostassociated disease incidence (pathogenic diversity) observed in the SJV almond orchards previously described (19).

The distribution of the 39 haplotypes among the 146 isolates from two different almond orchards in this study did not reveal any seasonal or annual variation (Table 2). This could likely be attributed to the high rate of clonal reproduction rather than recombination or random point mutation, especially for the short time scale. A multigene phylogenetic analysis indicates that, historically, X. fastidiosa has been a clonal organism (54). Also, this bacterium appears to have low ratios of recombination to point mutation on a per-allele basis and a per-nucleotide basis compared with other bacteria (52). Moreover, an analysis of rapidly evolving genes suggests that $X$. fastidiosa is largely clonal (38). The results from this study are consistent with these hypotheses. The strength of allelic association was verified by significant LD between the greater number of SSR locus pairs across the overall isolates. Moreover, the $I_{\mathrm{A}}$ and $\bar{r}_{d}$ as the measure of multilocus genotypic equilibrium clearly suggest significant clonal reproduction within the population obtained from each different orchard or host cultivar.

Although there is a lack of seasonal or annual variation in the distributions of $X$. fastidiosa haplotypes (mostly likely due to the higher rate of clonality), haplotypes were notably linked via host association(Sonora and Nonpareil). Population genetic analyses using various approches (UPGMA, PCoA, and STRUCTURE) consistently identified two major genetic clusters, where genetic structure was not associated with any particular season or year but two distinct clusters were consistently associated with the two host cultivars. Cluster I was associated with Sonora and cluster II was most often associated with Nonpareil (Figs. 1, 2, and 3). When comparing the molecular genetics of $X$. fastidiosa strains cultured from various plants, Hendson et al. (20) found that most ALS strains formed two distinct groups (clusters) based on random amplified polymorphism DNA PCR and contour-clamped homogeneous electric field (CHEF) gel electrophoresis. Until now, however, little information has been generated to describe the genetic structure of $X$. fastidiosa associated with ALS disease in multiple affected trees in select orchards of California's SJV. Using single nucleotide polymorphism analysis of the $16 \mathrm{~S}$ ribosomal RNA gene, Chen et al. (8) reported that two distinct haplotypes (G-type and A-type) of $X$. fastidiosa were associated with ALS disease-affected almond trees in similar locations. Two types of $X$. fastidiosa associated with ALS disease in the SJV were further substantiated by restriction fragment length polymorphism analysis of an RST31-RST33 locus, and a unique bacterial colony morphology was further associated with the A-type $X$. fastidiosa strains (8).

The overall results of our analyses of $X$. fastidiosa from two different host cultivars clearly suggest that genetic adaptation of $X$. fastidiosa occurred through the selection pressure exerted by host plants, or even cultivars, where one group (cluster I) was associated with Sonora and another group (cluster II) with Nonpareil in two studied almond orchards or even within the same almond production sites.

Although the two genetic groups observed in the present study were mainly distributed between two cultivars (Sonora and Nonpareil), the overlapping of a small number of haplotypes between these two host plants within the same orchard (orchard B) was also observed from the distribution of repeated haplotype classes, as well as from the UPGMA dendrogram, PcoA plot, and STRUCTURE assignment. This could most likely be due to the dispersal of this bacterium among adjacent host plants by the frequent movement of insect vectors. Moreover, the occurrence of cluster II (Nonpareil dominant strain) within Sonora isolates in orchard A in August 2004 may have resulted from dispersal of fewer strains from the adjacent Nonpareil host plants or other sources. However, the nonoccurrence of strains of this genetic group at orchard A in the later months and year suggest that Nonpareil strains appear to be less successful in adaptation than Sonora. Hostassociated genetic adaptation is clearly observed in $X$. fastidiosa species based on the degree of pathogenicity on selected plants $(7,12,20)$.

Two distinct genetic structures largely associated with two different almond cultivars (Sonora and Nonpareil) were identified among $X$. fastidiosa populations associated with ALS disease. These findings may provide information to better understand the genetic diversity and the evolutionary potential of $X$. fastidiosa populations in California.

\section{ACKNOWLEDGMENTS}

We thank P. Sahota and M. Schreiber for technical assistance. Funding for this project was provided by the USDA-ARS Xylella fastidiosa CRIS Project. Trade names or commercial products in this publication are mentioned 
solely for the purpose of providing specific information and does not imply recommendation or endorsement by the United States Department of Agriculture (USDA). USDA is an equal employment opportunity provider.

\section{LITERATURE CITED}

1. Agapow, P. M., and Burt, A. 2001. Indices of multilocus linkage disequilibrium. Mol. Ecol. Notes 1:101-102.

2. Almeida, R. P. P., Nascimento, F. E., Chau, J., Prado, S. S., Tsai, C. W., Lopes, S. A., and Lopes, J. R. S. 2008. Genetic structure and biology of Xylella fastidiosa strains causing disease in citrus and coffee in Brazil. Appl. Environ. Microbiol. 74:3690-3701.

3. Almeida, R. P. P., and Purcell, A. H. 2003. Biological traits of Xylella fastidiosa strains from grapes and almonds. Appl. Environ. Microbiol. 69: 7447-7452.

4. Brown, A. H. D., Feldman, M. W., and Nevo, E. 1980. Multilocus structure of natural populations of Hordeum spontaneum. Genetics 96:523-536.

5. Cariddi, C., Saponari, M., Boscia, D., De Stradis, A., Loconsole, G., Nigro, F., Porcelli, F., Potere, O., and Martell, G. P. 2014. Isolation of a Xylella fastidiosa strain infecting olive and oleander in Apulia, Italy. J. Plant Pathol. 96:1-5.

6. Chatelet, D. S., Wistrom, C. M., Purcell, A. H., Rost, T. L., and Matthews, M. A. 2011. Xylem structure of four grape varieties and 12 alternative hosts to the xylem-limited bacterium Xylella fastidiosa. Ann. Bot. (Lond.) 108:73-85.

7. Chen, J., Chang, C. J., Jarret, R. L., and Gawel, N. 1992. Genetic variation among Xylella fastidiosa strains. Phytopathology 82:973-977.

8. Chen, J., Groves, R., Civerolo, E. L., Viveros, M., Freeman, M., and Zheng, Y. 2005. Two Xylella fastidiosa genotypes associated with almond leaf scorch disease on the same location in California. Phytopathology 95: 708-714.

9. Chen, J., Livingston, S., Groves, R., and Civerolo, E. L. 2008. High throughput PCR detection of Xylella fastidiosa directly from almond tissues. J. Microbiol. Methods 73(1):57-61.

10. Coletta-Filho, H. D., Bittleston, L. S., and Almeida, R. P. P. 2011. Spatial genetic structure of a vector-borne generalist pathogen. Appl. Environ. Microbiol. 77:2596-2601.

11. Coletta-Filho, H. D., Takita, M. A., de Souza, A. A., Aguilar-Vildoso, C. I., and Machado, M. A. 2001. Differentiation of strains of Xylella fastidiosa by a variable number of tandem repeat analysis. Appl. Environ. Microbiol. 67:4091-4095.

12. da Costa, P. I., Franco, C. F., Miranda, V. S., Teixeira, D. C., and Hartung, J. S. 2000. Strains of Xylella fastidiosa rapidly distinguished by arbitrarily primed-PCR. Curr. Microbiol. 40:279-282.

13. Davis, M. J., French, W. J., and Schaad, N. W. 1981. Isolation and culture of the bacteria associated with phony peach disease and plum leaf scald. (Abstr.) Phytopathology 71:869.

14. Davis, M. J., Purcell, A. H., and Thomson, S. V. 1978. Pierces disease of grapevines isolation of the causal bacterium. Science 199:75-77.

15. Davis, M. J., Thomson, S. V., and Purcell, A. H. 1980. Etiological role of a xylem-limited bacterium causing Pierce's disease in almond leaf scorch. Phytopathology 70:472-475.

16. Euzeby, J. P. 1997. List of bacterial names with standing in nomenclature: A folder available on the Internet. Online publication: List of prokaryotic names with standing in nomenclature. Int. J. Syst. Bacteriol. 47(2): 590-592.

17. Evanno, G., Regnaut, S., and Goudet, J. 2005. Detecting the number of clusters of individuals using the software STRUCTURE: A simulation study. Mol. Ecol. 14:2611-2620.

18. Freitag, J. H. 1954. N. W. F. 1954. Natural infectivity of leafhopper vectors of Pierce's disease virus of grape in California. Phytopathology 44:7-11.

19. Groves, R. L., Chen, J., Civerolo, E. L., Freeman, M. W., and Viveros, M. A. 2005. Spatial analysis of almond leaf scorch disease in the San Joaquin Valley of California: Factors affecting pathogen distribution and spread. Plant Dis. 89:581-589.

20. Hendson, M., Purcell, A. H., Chen, D. Q., Smart, C., Guilhabert, M., and Kirkpatrick, B. 2001. Genetic diversity of Pierce's disease strains and other pathotypes of Xylella fastidiosa. Appl. Environ. Microbiol. 67: 895-903.

21. Islam, M. S., Glynn, J. M., Bai, Y., Duan, Y. P., Coletta, H. D., Kuruba, G., Civerolo, E. L., and Lin, H. 2012. Multilocus microsatellite analysis of 'Candidatus Liberibacter asiaticus' associated with citrus Huanglongbing worldwide. BMC Microbiol. 12:39.

22. Jakobsson, M., and Rosenberg, N. A. 2007. CLUMPP: A cluster matching and permutation program for dealing with label switching and multimodality in analysis of population structure. Bioinformatics 23:1801-1806.

23. Janse, J. D., and Obradovic, A. 2010. Xylella fastidiosa: Its biology, diagnosis, control and risks. J. Plant Pathol. 92:S35-S48.
24. Kamvar, Z. N., Tabima, J. F., and Grünwald, N. 2014. Poppr: An R package for genetic analysis of populations with clonal, partially clonal, and/or sexual reproduction. Peer J. 2:e281.

25. Killiny, N., and Almeida, R. P. P. 2009. Xylella fastidiosa Afimbrial adhesins mediate cell transmission to plants by leafhopper vectors. Appl. Environ. Microbiol. 75:521-528.

26. Krugner, R., Sisterson, M. S., Chen, J., Stenger, D. C., and Johnson, M. W. 2014. Evaluation of olive as a host of Xylella fastidiosa and associated sharpshooter vectors. Plant Dis. 98 1186-1193.

27. Lee, R. F., Beretta, M. J. G., Hartung, J. H., Hooker, M. E., and Derrick, K. S. 1993. Citrus variegated chlorosis: Confirmation of a Xylella fastidiosa as the causal agent. Summa Phytopathol. 19:123-125.

28. Leu, L. S., and Su, C. C. 1993. Isolation, cultivation, and pathogenicity of Xylella fastidiosa, the causal bacterium of pear leaf scorch disease in Taiwan. Plant Dis. 77:642-646.

29. Lin, H., Civerolo, E. L., Hu, R., Barros, S., Francis, M., and Walker, M. A. 2005. Multilocus simple sequence repeat markers for differentiating strains and evaluating genetic diversity of Xylella fastidiosa. Appl. Environ. Microbiol. 71:4888-4892.

30. Lin, H., Islam, M. S., Bai, Y., Wen, A., Lan, S. Q., Gudmestad, N. C., and Civerolo, E. L. 2012. Genetic diversity of 'Candidatus Liberibacter solanacearum' strains in the United States and Mexico revealed by simple sequence repeat markers. Eur. J. Plant Pathol. 132:297-308.

31. Lin, H., Islam, M. S., Morano, L., Groves, R., Bextine, B., Civerolo, E., and Walker, M. A. 2013. Genetic variation of Xylella fastidiosa associated with grapevines in two major viticultural regions in the United States: California and Texas. J. Plant Pathol. 95:329-337.

32. Loconsole, G., Potere, O., Boscia, D., Altamura, G., Djelouah, K., Elbeaino, T., Frasheri, D., Lorusso, D., Palmisano, F., Pollastro, P., Silletti, M. R., Trisciuzzi, N., Valentini, F., Savino, V., and Saponari, M. 2014. Detection of Xylella fastidiosa in olive trees by molecular and serological methods. J. Plant Pathol. 96:7-14.

33. McGaha, L. A., Jackson, B., Bextine, B., McCullough, D., and Morano, L. 2007. Potential plant reservoirs for Xylella fastidiosa in South Texas. Am. J. Enol. Vitic. 58:398-401.

34. Melanson, R. A., Sanderlin, R. S., McTaggart, A. R., and Ham, J. H. 2012. A Systematic Study Reveals that Xylella fastidiosa Strains from Pecan Are Part of X. fastidiosa subsp. multiplex. Plant Dis. 96:1123-1134.

35. Minsavage, G. V., Thompson, C. M., Hopkins, D. L., Leite, R. M. V. B., and Stall, R. E. 1994. Development of polymerase chain reaction protocol for the detection of Xylella fastidiosa in plant tissue. Phytopathology 84: 456-461

36. Mircetich, S. M., Lowe, S. K., Moller, W. J., and Nyland, G. 1976. Etiology of almond leaf scorch disease and transmission of the causal agent. Phytopathology 66:17-24.

37. Nei, M., Tajima, F., and Tateno, Y. 1983. Accuracy of estimated phylogenetic trees from molecular data. II. Gene frequency data. J. Mol. Evol. 19:153-170.

38. Nunney, L., Stouthamer, R., and Luck, R. F. 2003. Genomic wide identification of rapidly evolving genes in Xylella fastidiosa: Key elements in the systematic identification of host strains and in the search for planthost pathogenicity candidate genes. Pages 26-29 in: Proc. 2003 Pierces Disease Res. Symp. Coronado CA.

39. Nunney, L., Hopkins, D. L., Morano, L. D., Russell, S. E., and Stouthamer, R. 2014. Intersubspecific recombination in Xylella fastidiosa strains native to the United States: Infection of novel hosts associated with an unsuccessful invasion. Appl. Environ. Microbiol. 80:1159-1169.

40. Nunney, L., Vickerman, D. B., Bromley, R. E., Russell, S. A., Hartman, J. R., Morano, L. D., and Stouthamer, R. 2013. Recent evolutionary radiation and host plant specialization in the Xylella fastidiosa subspecies native to the United States. Appl. Environ. Microbiol. 79: 2189-2200.

41. Peakall, R., and Smouse, P. 2006. GENALEX 6: Genetic analysis in Excel. Population genetic software for teaching and research. Mol. Ecol. Notes 6:288-295.

42. Pritchard, J., Stephens, M., and Donnelly, P. 2000. Inference of population structure using multilocus genotype data. Genetics 155:945-959.

43. Purcell, A. H., and Hopkins, D. L. 1996. Fastidious xylem-limited bacterial plant pathogens. Annu. Rev. Phytopathol. 34:131-151.

44. Purcell, A. H., Saunders, S. R., Hendson, M., Grebus, M. E., and Henry, M. J. 1999. Causal role of Xylella fastidiosa in oleander leaf scorch disease. Phytopathology 89:53-58.

45. Randall, J. J., Goldberg, N. P., Kemp, J. D., Radionenko, M., French, J. M., Olsen, M. W., and Hanson, S. F. 2009. Genetic analysis of a novel Xylella fastidiosa subspecies found in the Southwestern United States. Appl. Environ. Microbiol. 75:5631-5638.

46. Raymond, M., and Rousset, F. 1995. GENEPOP (version 1.2): Population genetics software for exact tests and ecumenicism. J. Hered. 86: 248-249. 
47. Redak, R. A., Purcell, A. H., Lopes, J. R. S., Blua, M. J., Mizell, R. F., and Andersen, P. C. 2004. The biology of xylem fluid-feeding insect vectors of Xylella fastidiosa and their relation to disease epidemiology. Annu. Rev. Entomol. 49:243-270.

48. Rosenberg, N. A. 2004. DISTRUCT: A program for the graphical display of population structure. Mol. Ecol. Notes 4:137-138.

49. Sanborn, R. R., Mircetich, S. M., Nyland, G., and Moller, W. J. 1974. "Golden death" a new leaf scorch threat to almond growers. Calif. Agric. 28:4-5.

50. Sanderlin, R. S., and Heyderich-Alger, K. I. 2000. Evidence that Xylella fastidiosa can cause leaf scorch disease of pecan. Plant Dis. 84:12821286.

51. Saponari, M., Boscia, D., Nigro, F., and Martelli, G. P. 2013. Identification of DNA sequences related to Xylella fastidiosa in oleander, almond and olive trees exhibiting leaf scorch symptoms in Apulia (Southern Italy). J. Plant Pathol. 95:668.

52. Scally, M., Schuenzel, E. L., Stouthamer, R., and Nunney, L. 2005. Multilocus sequence type system for the plant pathogen Xylella fastidiosa and relative contributions of recombination and point mutation to clonal diversity. Appl. Environ. Microbiol. 71:8491-8499.

53. Schaad, N. W., Postnikova, E., Lacy, G., Fatmi, M., and Chang, C.-J. 2004. Xylella fastidiosa subspecies: X. fastidiosa subsp. piercei, subsp. nov., X. fastidiosa subsp. multiplex subsp. nov., and X. fastidiosa subsp. pauca subsp. nov. Syst. Appl. Microbiol. 27:290-300.

54. Schuenzel, E. L., Scally, M., Stouthamer, R., and Nunney, L. 2005. A multigene phylogenetic study of clonal diversity and divergence in North American strains of the plant pathogen Xylella fastidiosa. Appl. Environ. Microbiol. 71:3832-3839.

55. Shapland, E. B., Daane, K. M., Yokota, G. Y., Wistrom, C., Connell, J. H., Duncan, R. A., and Viveros, M. A. 2006. Ground vegetation survey for Xylella fastidiosa in California almond orchards. Plant Dis. 90: 905-909.

56. Su, C. C., Chang, C. J., Yang, W. J., Hsu, S. T., Tzeng, K. C., Jan, F. J., and Deng, W. L. 2012. Specific characters of 16S rRNA gene and 16S-23S rRNA internal transcribed spacer sequences of Xylella fastidiosa pear leaf scorch strains. Eur. J. Plant Pathol. 132:203-216.

57. Tamura, K., Dudley, J., Nei, M., and Kumar, S. 2007. MEGA4: Molecular evolutionary genetics analysis (MEGA) software Version 4.0. Mol. Biol. Evol. 24:1596-1599.

58. Teviotdale, B. L., and Connell, J. H. 2003. Almond leaf scorch. Online publication. Univ. Calif. Div. Agric. Nat. Resour. Publ. 8106. http:// anrcatalog.ucdavis.edu/pdf/8106.pdf

59. Verniere, C., Bui Thi Ngoc, L., Jarne, P., Ravigne, V., Guerin, F., Gagnevin, L., Le Mai, N., Chau, N. M., and Pruvost, O. 2014. Highly polymorphic markers reveal the establishment of an invasive lineage of the citrus bacterial pathogen Xanthomonas citri pv. citri in its area of origin. Environ. Microbiol. 16:2226-2237.

60. Viveros, M. 2003. Almond leaf scorch, almond version of Pierce's disease, increasing in Kern County. Online publication. Kern/Tulare GWSS Update, University of California Cooperative Extension. http://cekern.ucdavis.edu/ newsletters/November_14,_200335323.pdf

61. Wells, J. M., Raju, B. C., Huang, H.-Y., Weisburg, W. G., Mandelco-Paul, L., and Brenner, D. J. 1987. Xylella fastidiosa gen. nov., sp. nov.: Gramnegative, xylem limited, fastidious plant bacteria related to Xanthomonas spp. Int. J. Syst. Bacteriol. 37:136-143.

62. Yuan, X., Morano, L., Bromley, R., Spring-Pearson, S., Stouthamer, R., and Nunney, L. 2010. Multilocus sequence typing of Xylella fastidiosa causing Pierce's disease and oleander leaf scorch in the United States. Phytopathology 100:601-611. 